\title{
SUBMISSÃO DE TRABALHOS
}

A submissão de novos trabalhos deverá ser feita por meio do Portal de Periódicos Eletrônicos da PUC Minas, no site http://periodicos.pucminas.br/index.php/arquiteturaeurbanismo, onde estão disponibilizadas as normas para apresentação de trabalhos, também em inglês e espanhol.

\section{NORMAS PARA APRESENTAÇÃO DETRABALHOS}

1. Serão aceitos para apreciação trabalhos das seguintes modalidades:
a) artigos de revisão relacionados às diversas áreas temáticas da arquitetura e urbanismo;
b) artigos de pesquisa que apresentem novas contribuições para a arquitetura e urbanismo;
c) artigos associados a dissertações de mestrado e teses de doutorado;
d) artigos relacionados ao ensino de arquitetura e urbanismo;
e) resenhas de livros, artigos e filmes de significativa importância para a arquitetura e urbanismo;
f) projetos de arquitetura e urbanismo, discutidos teórica e metodologicamente;
g) entrevistas.

2. Só serão aceitos trabalhos inéditos e ainda não publicados.

3. A critério do Conselho Editorial poderão ser aceitos trabalhos que não se enquadrem nos itens acima, considerada a sua especial relevância.

4. Os trabalhos deverão atender as seguintes especificações:

a) Trabalho digitado em Word for Windows, fonte Times New Roman, corpo 12, entrelinha 1,5, em formato A4, com margens superior, inferior e direita de $2 \mathrm{~cm}$, e margem esquerda de $3 \mathrm{~cm}$.

b) O trabalho completo (incluindo resumos, notas, ilustrações e referências bibliográficas) deverá ter no mínimo 12 e no máximo 20 páginas.

c) Título e subtítulo objetivos, de no máximo 50 caracteres, apresentado de modo bilíngüe (português / inglês).

d) Caso o trabalho seja decorrente de pesquisas, dissertações, teses ou similares, explicitar em nota de rodapé associada ao título.

e) Nome completo do autor ou autores, complementado com as seguintes informações, indicadas em nota de rodapé (uma para cada autor): formação/instituição, titulação/instituição, filiação profissional.

f) Resumo do trabalho, apresentado de modo bilíngüe (português/inglês), contendo no máximo 500 caracteres cada.

g) Palavras-chave / key words (mínimo de 3 e máximo de 5), apresentadas de modo bilíngüe (português/inglês).

h) Citações, notas e referências bibliográficas devem ser apresentadas segundo as normas da ABNT.

i) As notas devem ser de rodapé.

j) As imagens de qualquer natureza (gráficos, figuras, fotos, mapas e outras) devem ser perfeitamente legíveis em preto e branco e apresentadas de duas maneiras:

- Ao longo do texto, em baixa resolução, numeradas, acompanhadas de legendas específicas, em Times New Roman, tamanho 10, com identificação de fonte (as imagens não podem, em hipótese alguma, ter problema de direitos autorais).

- Cada uma das imagens inseridas ao longo do trabalho deve ainda ser submetida pelo sistema, conforme consta no "Passo 4: Envie Documento Suplementar". Elas devem estar em formato JPG ou TIF, com tamanho real de no mínimo 1000 pixels na horizontal e altura proporcional, de modo a garantir boa qualidade para reprodução gráfica.

k) Endereço completo para correspondência (com CEP) e e-mail, de cada um dos autores, inseridos ao final do trabalho.

5. A identificação de autoria do trabalho será removida do arquivo pela equipe editorial para avaliação por pares, garantindo desta forma o critério de sigilo da revista.

6. Não serão aceitos trabalhos que não atendam as especificações e exigências acima.

\section{CONDIÇÕES GERAIS}

A colaboração não é remunerada.

O artigo ficará disponibilizado por tempo indeterminado.

O site dos Cadernos de Arquitetura e Urbanismo permite acesso aos artigos por links diretos. 


\section{NORMS FOR SUBMISSION OF PAPERS}

1. The following kinds of papers will be accepted for evaluation:
a) review articles related to the various thematic areas of architecture and urbanism;
b) research articles that represent new contributions to architecture and urbanism;
c) articles related to master's dissertations and doctoral theses;
d) articles about the teaching of architecture and urbanism;
e) book, article and film reviews of relevance to architecture and urbanism;
f) architectural and urbanistic designs, theoretically and methodologically discussed;
g) interviews.

2. Only original and unpublished papers will be accepted.

3. The Editorial Board can accept particularly relevant papers not included in the categories mentioned above.

4. Papers must meet the following specifications:
a) Text typed in Word for Windows; font Times New Roman, size 12, line space 1.5 in A4 format; top, bottom and right margins of $2 \mathrm{~cm}$ and left margin of $3 \mathrm{~cm}$.
b) The whole paper (including abstract, notes, illustrations and references) must have a minimum of 12 and a maximum of 20 pages.
c) Objective title and subtitle, maximum of 50 characters, presented in Portuguese and in English.
d) For papers resulting from research, dissertations or theses, it must be indicated in a footnote associated to the title.
e) Author's or authors' full name(s), with the following information in a footnote: qualification / institution, title / institution, professional affiliation.
f) Abstract in Portuguese and in English, containing a maximum of 500 characters each.
g) Key words (minimum 3 and maximum 5) in English and in Portuguese.
h) Quotations, footnotes and references must comply with the ABNT norms.
i) Notes must be presented as footnotes.
j) Images of any type (graphics, pictures, photos, maps and others) must be perfectly legible in black and white and presented in two ways:
- Throughout the text, in low resolution, numbered, with specific legends in Times New Roman, size 10,
followed by source (pictures cannot have, under any circumstances, copyright claims);
- Each image inserted along the text must still be put through the system, as shown in "Step 4: Upload supplementary document." The images must be in JPG or TIF format, with a size of at least 1000 horizontal pixels and proportional height so as to ensure good quality for graphic reproduction.
k) Complete mailing address (with zip code) and e-mail of each author, inserted at the end of the paper.

5. The identification of the paper authorship will be removed from the file by the editorial team, thus ensuring the criterion of confidentiality of the journal.

6. Papers that do not meet the specifications and requirements above will not be accepted.

\section{GENERAL CONDITIONS}

The collaboration is unpaid.

The article will be available indefinitely.

The site of the Journal of Architecture and Urban Design allows access to articles by direct links. 


\section{DIRECTRICES DE DOCUMENTOS}

1. Se aceptarán trabajos para evaluación de los siguientes tipos:
a) artículos de revisión relacionados a las diversas áreas temáticas de la arquitectura y urbanismo;
b) artículos de pesquisa que presenten nuevas contribuciones para la arquitectura y urbanismo;
c) artículos asociados a disertaciones de master y a tesis de doctorado;
d) artículos relacionados a la enseñanza de arquitectura y urbanismo que relaten nuevas experiencias didácti- co-pedagógicas:
e) resúmenes de libros, artículos y películas de significativa importancia para la arquitectura y urbanismo;
f) proyectos de arquitectura y urbanismo, discutidos teórica y metodológicamente;
g) entrevistas.

2. Sólo se aceptarán trabajos inéditos, aún no publicados.

3. A criterio del Consejo Editorial, podrán aceptarse trabajos que no se encuadren en los puntos arriba indicados dada su especial relevancia.

4. Los trabajos deberán tener las siguientes especificaciones:

a) Digitalizado en fuente Word for Windows, tipo Times New Roman, cuerpo 12, interlineado 1,5 en papel tamaño A4, márgenes superior, inferior y derecho de $2 \mathrm{~cm}$ y margen izquierdo de $3 \mathrm{~cm}$.

b) El trabajo completo (incluyendo resúmenes, notas, ilustraciones y referencias bibliográficas) deberá tener como mínimo 12 y como máximo 20 páginas.

c) Título y subtítulo objetivos, con un máximo de 50 caracteres, presentado de modo bilingüe (Español / Inglés).

d) Si el trabajo es consecuencia decurrente de investigaciones, disertaciones, tesis o similares, debe explicitárselo en nota de pie de página asociada al título.

e) Nombre completo del autor o autores, complementado con las siguientes información, indicadas en nota de pie de página: formación / institución /, titulación / institución/, afiliación profesional.

f) Resumen presentado en forma bilingüe (Español / Inglés), con un máximo de 500 caracteres cada.

g) Palabras clave (mínimo de 3 y máximo de 5), presentados en modo bilingüe (Español / Inglés) (palabras clave / key words).

h) Citas, notas y referencias bibliográficas presentados según las normas de la ABNT.

i) Las notas deberán ser de pie de página.

j) Las imágenes de cualquier tipo (gráficos, imágenes, fotos, mapas y otros) deberán ser perfectamente legibles en blanco y negro y se presenta en dos formas:

- A lo largo del texto, de baja resolución, numeradas, acompañadas de leyendas específicas en Times New Roman, cuerpo 10, donde deben constar las fuentes (las imágenes no pueden, bajo ninguna circunstancia, tener problemas con los derechos de autor).

- Cada una de las imágenes incluidas a lo largo de la obra aún debe ser insertado por medio del sistema, como se muestra en el "Paso 4: Cargar complementaria." Deben estar en formato JPG oTIF, con un tamaño mínimo de 1000 píxeles horizontales y altura proporcional, para asegurar buena calidad de reproducción gráfica.

k) Dirección postal completa y e-mail (indicados para cada autor al final del trabajo).

5. La identificación de la autoría de la obra será retirada de los autos por el equipo editorial, lo que garantiza la confidencialidad de los criterios revisados.

6. No se aceptarán trabajos que no cumplan las especificaciones y exigencias arriba indicadas.

\section{CONDICIONES GENERALES}

La colaboración no es remunerada.

El artículo estará disponible por tiempo indefinido.

El sitio de la Revista de Arquitectura y Urbanismo permite el acceso a artículos por enlaces directos. 
Impresso em couché liso $90 \mathrm{~g} / \mathrm{m}^{2}$ com tipos da família Univers pela Gráfica e Editora O Lutador no inverno de 2013. 
